[Sullivan, K. (2001). Teachers and Schools Succeeding Against the Odds: An Exploratory Case Study. New Zealand Annual Review of Education, 10, 203-220]

\section{Teachers and Schools Succeeding Against the Odds: An Exploratory Case Study}

\section{KEITH SULLIVAN}

\section{Abstract:}

This article examines how one low-decile New Zealand secondary school has managed to succeed against the odds. After examining Education Review Office and Ministry of Education responses to school failure, the paper looks at the influence of recent educational reform upon teaching, and at what the teachers in the case study school have done within their professional practice to create a culture of success. It argues that the teachers of the school have been professional in defending themselves against governmental attacks, and in their innovative approaches to a difficult teaching context. As a means of generating more understanding, the article finishes by exploring first of all the role of "teacher as hero" as portrayed in film, and secondly the relationship between schooling and cultural capital.

$\mathrm{T}$ Ika Nui a Maui Secondary School (a pseudonym) is a decile three multiethnic secondary school (29\% Maori, 5\% Pacific Island, 3\% Asian and $63 \%$ pakeha) located in the Hawkes Bay region of New Zealand. Recently, a teenage parent unit designed to support school-age mothers to return to school was in the news. New Zealand's Prime Minister, the Right Honourable Helen Clark, found time in her busy schedule to visit the school and to officially open the Unit. It had been created through the efforts of a small group of very committed women and was fully supported by the school. The Prime Minister was heard to comment that she was increasingly being called upon by schools to open their new technology centres, but that she found the teenage parent unit to be of more importance.

When discussing the school's commitment to the project, the Principal remarked that:

\section{Keith Sullivan}

If we had followed the rules of accountability, this whole thing would not have happened but we did it because it needed to be done. The government needs to change its policies so we are not placed in this position.

The subtext of these two related responses could be read as follows:

i. Although the Prime Minister may think that meeting the needs of young solo mothers is laudable, society currently places more value on pragmatic developments such as hi-tech units rather than on social caring schemes such as the teenage parent unit.

ii. It would probably have been easier for Te Ika Nui a Maui Secondary School to get funding and support for a hi-tech unit than for a teenage parent unit.

iii. The principal and the school think that it is important to address the social as well as the academic needs of their community, but reporting restraints make this difficult.

iv. This set of responses is symbolic: "doing the right thing" for the students and the general community of the school is more important for the principal than following the popular trend to cater for the perceived hi-tech needs of the New Zealand economy.

v. At the macro-level, this could be seen as illustrating a tension in society between pragmatism and meeting the perceived needs of the market, and acting in a socially responsible fashion.

Since the educational reforms of the 1980s, we have moved away from the concept of education as a public good to education as a commodity to be bartered for in the market place like any other commodity (Grace, 1990). To see education in this way without taking into account all the complexities and inequalities within New Zealand society is clearly ludicrous. One result of the playing out of this economic rationalist approach has been the creation of "winner" and "loser" schools, and these so-called "loser" schools have been spotlighted in recent years by the Education Review Office (ERO).

The illustration cited above is symbolic of the willingness of the principal and teachers of one school (a school with many ingredients of the recipe for becoming a "loser" school) to put themselves on the line for what they believe in, and to continue to support, by implication, the socially responsible notion of education as a public good. These staff members have put much planning and hard work into creating success against the odds for some pupils of Te Ika Nui a Maui School, even 
though it must often feel as if they are pushing a massive cart full of kids up a difficult and slippery slope. Despite their best efforts, a large proportion of the student population will inevitably "abandon ship" (and in educational terms, drown) before reaching a safe haven.

\section{An Alternative Theoretical and Methodological Perspective}

This article describes the early stages of an ethnographic study of Te Ika Nui a Maui Secondary School. The school suffers many of the disadvantages of the schools of concern to the ERO, but it is a school that has not only succeeded "against the odds", but is actually thriving. ${ }^{1}$ The data for this article have been collected through participant observation, and through recording and transcribing semi-structured and structured interviews. Individual and collective narratives have been used critically in a "grounded theory" approach, in an attempt to to explain what is occurring and why.

As background to this article I will discuss how the ERO and the Ministry of Education have responded to the "poor performance" of low-decile schools with a similar profile to the case study school. A brief description will then be given of the policy context within which New Zealand schools have been operating since 1988, and of two particular ways in which staff of Te Ika Nui a Maui Secondary School have asserted their position as teaching professionals. Against a background of more general issues of failure and success in schools, within the context of New Zealand's education reforms, an outline will then be given of the individual success-oriented culture of the school as an explanation of why it has managed to succeed against the odds.

\section{A Concern for Poor Performance}

In recent years in New Zealand, the ERO has produced a number of reports that have been critical of poor performance by schools in the Far North, the East Cape and in the South Auckland suburbs of Mangere and Otara (ERO, 1996, 1997, 1998a, 1998b, 1999). The ERO's criticisms are levelled at low-decile schools with large indigenous Maori and immigrant minority Pacific Island and Asian populations. Improving Schooling in Mangere and Otara (1996) states that for the 45 schools located in these suburbs:

- 42 percent are performing very poorly or under-performing;

- 27 percent are in the highest category of risk of non-performance, that is, they have been subject to at least one follow-up ERO review;
- 15 percent are under-performing, although the level of risk has not been considered sufficient to justify a follow-up review (p. 3).

The report goes on to argue that although there are a number of clear reasons linked to disadvantage which account for school failure (low incomes, high rates of unemployment, crowded housing and poor child health), a significant proportion of the schools still manage a degree of success:

It is commonly asserted that there is a strong link between school failure and the degree of disadvantage in a socio-economic setting. There are, however, some $20 \%$ of the schools in these two districts that provide an effective education for their students. Their boards, principals and teachers have, with various degrees of success, met the challenges of their students' backgrounds and concentrated on teaching and learning to the benefit of their students. (p. 4)

I would maintain that this is a superficial reading of the situation. Because some schools manage to obtain some degree of success for their students, this does not mean that their students are not disadvantaged. The ERO, however, with its school effectiveness stance ${ }^{2}$ adopts a deficit response in casting the acceptable 20 percent as "successes" and the rest as failures.

[We are concerned about] the poor performance of one or more of the board of trustees, the principal or teaching staff and the effect of this poor performance on the education of their students, [and] based on an analysis of why such a high level of poor performance exists, the report recommends ways in which board, management and teaching performance could be improved. (p. 4)

In such statements there is always an element of truth, and those schools that have had a degree of success need to be acknowledged and applauded. However, there are a number of challenges that can be made to the assumptions underlying both the "successful schools" literature generally, and the stance of the ERO in its rather glib estimations of poor performance. Largely as a response to these ERO reports, the Ministry of Education has developed several initiatives aimed at improving school performance. The response in Mangere and Otara is entitled Strengthening Education in Mangere and Otara (SEMO). Several reports have been produced about the implementation and subsequent evaluation of this project (Timperley, Robinson \& Bullard, 1999; and Robinson, Timperley \& Bullard, 2000), whose main intention seems to be the development of a strong school/community 
relationship in order to create foundations for educational support and, as a consequence, the improvement of educational outcomes.

\section{Setting the Context}

With the so-called reform of educational administration in the late $1980 \mathrm{~s}$ (Administering for Excellence and Tomorrow's Schools, both 1988), education in New Zealand was drastically altered. Self-governing schools became the norm, with teachers recast as employees, principals as managers, and parents as governors and employers in the form of a board of trustees. For teachers, this has meant a gradual erosion of their conditions of service and status as professionals. They have been accused of provider-capture (Sullivan, 1994, 1997) and, along with an apparently rotten and inefficient system, were held responsible for the contemporary crisis in business, and the poor preparation of students for participation in the economy (Treasury, 1987).

In order to control teachers more effectively, a number of strategies were developed:

i. A Teachers' Registration Board (TRB) was set up by the government as a regulatory body. An Educational Council is now in the process of being established. The government is promoting this as a professional body for teachers, but it is likely to extend the present regulatory powers of the TRB - especially if during its 18-month establishment period it is run by government appointees, as is planned (Sullivan, 1999).

ii. The Education Review Office was set up to audit schools regularly, and to make teachers accountable.

iii. Performance contracts were made between teachers as employees and principals as managers.

The reforms also promoted "choice" for parents and students, which means in fact that schools now compete in a quasi-marketplace for students who count as EFTS (equivalent full-time students), which effectively translates into dollars (Gordon, 1997). School zoning was abolished (but has recently been reinstated). The argument goes that if you want to compete in a market situation, you have to provide top quality teaching and learning, and if you don't, well, you will have to learn to play the game or you won't survive (on the so-called level playing field). In a country where inequality is clearly widespread, schools in areas like the Far North, the East Cape, Mangere and Otara, and schools like Te Ika Nui a Maui are hard-pressed to compete. The Smithfield research (Lauder et al., 1999) clearly showed that schools in low-SES communities lost out no matter how hard they tried to market themselves and to compete, and that low-SES schools emptied as middle-class Pakeha competed to get in to the highest schools (or as high as possible) in the newly instituted league tables (Fiske \& Ladd, 2000). No-one in the 1970s would have dreamed that government policy would, within the next two decades, introduce white and middle-class flight into supposedly non-racist and classless New Zealand.

Since these reforms were introduced, then, with this movement of "the most able" students away from low-SES schools, it has become increasingly difficult for schools like Te Ika Nui a Maui to survive.

\section{Succeeding Against the Odds: The Teachers}

Te Ika Nui School is successful in terms of achieving academic and sporting success, and a school environment that aims to develop and nurture full and balanced human beings.

The school has chosen a meaningful Ngati Kahungunu whakatauki ${ }^{3}$ to voice the purpose of its innovative programme for students at risk. It goes as follows: "Ehara taku toa e te toa takitahi engari e te toa takitini." This can be translated as: "My strength is not mine alone, it is a strength drawn from those around me." The spirit of cooperation and mutual support that is central to Maoritanga is also central for the staff of Te Ika Nui a Maui. I would also maintain that this is the backbone to the school's success in general.

There are two ways in which the teaching staff have been exemplary. Through maintaining a sense of professional integrity, when this was under threat, they have won out against the odds through:

(a) fighting for their professional status by resisting encroachments from politics and government policy in the form of bulk funding, and

(b) overturning an ERO report on their school that they felt was unjust.

The second way is through their vigorous development of innovative learning opportunities.

\section{Maintaining professional integrity}

(a) Te Ika Nui a Maui teachers reject bulk funding: A major debate was initiated when the reforms of educational administration were introduced. Budgets were to be devolved to schools, and they would 
receive a bulk grant from Government. Such budgets would provide all of a school's needs, including teachers' salaries. Schools would decide what they could and could not afford, and it was even suggested that they might wish to choose to make salary savings to buy computers.

It was strongly argued that the bulk funding of teachers' salaries would undermine their conditions of service, and negate their position as educational professionals. Bulk funding has been an ongoing battleground, and over the last five years it has pitted boards of trustees against teachers. Because of the offers of substantial extra resourcing if bulk funding was adopted, an increasing number of boards opted into the scheme, largely against the wishes of teachers, who saw such a move as short-term gain for long-term pain. In the case of Te Ika Nui a Maui, when the board of trustees passed a motion to adopt bulk funding against the will of the teachers, the teachers took the most extreme of stands against it and went out on strike. They also withdrew their goodwill (in terms of providing extra non-academic activities). What is more, it is clear that the teachers had thought the issues through and were very aware of the larger threat that bulk funding represented. They were concerned not only about the immediate effects, but also about the long-term ones, and they argued forcefully as follows:

i. The government was committed to reduce spending, and bulk funding was a long-term strategy for education sector cuts (as past experiences in Health, the Fire Service, and Children and Young Persons sectors had shown).

ii. Extra funding per school ( $\$ 304,000$ was the figure cited) for those opting into bulk funding was a bribe, and although in the short term more money would be available to schools that opted in, over time this would be reduced and would have a negative long-term effect on education.

iii. Ministry of Education statistics (1998) showed that 85 percent of teachers and 87 percent of schools were against bulk funding.

iv. The secondary teachers' professional organisation, the PPTA, and its 13,000 members, opposed it: "Lower decile schools such as Te Ika Nui a Maui will be unable to compete and will become 'loser schools'."

v. Bulk funding would mean the destruction of state-funded education: "As the bulk funding goes down, school fees charged to parents would rise in order to maintain the services offered." vi. "Bulk funding means that it will be individual Boards that have to negotiate salaries."

vii. The introduction of such a scheme would have disastrous effects on teacher recruitment and mobility.

The teachers stated that, while they did not want to take action to oppose the Board, they were totally committed to reversing the Board's decision, especially in light of its being made without proper consultation with parents, and with its being opposed by teaching staff, the Whanau Group, the Parents' League and senior students. The issue received much media attention and the teachers' stance was supported by the student and wider community. In the end, the Board was forced to reverse its original position, and the decision to adopt bulk funding was overturned.

(b) Doing battle with the ERO: The ERO produced a draft report about Te Ika Nui a Maui in 2000, containing some unfavourable comments. The school had been open about its problems, and had explained that it was trying some new initiatives. Seeds were being sown, but they would need time to grow and would need to be nurtured. This was part of the grand plan of the school.

The ERO's report aroused strong feelings. Staff at the school felt that its officers had misused information and had been unfair and unjust in their presentation of facts. The leadership of the school claimed to know of other schools that played the "ERO game" to their advantage, to present the school in its best light by making elaborate preparations and, in effect, hoodwinking the ERO. For example, some schools were known to organise camps so that the most disruptive students were not in the school during the ERO visit, and even to tell certain troublesome students not to show up at school during the visit of its officers.

Whereas recent research (Thrupp, 1999) has shown that taking ERO reports at face value can be problematic, it is nevertheless true that as far as the general public is concerned, lukewarm reports are potentially very damaging. In this case, the school rejected the report outright and argued with legal support that it should be re-written so as to represent more accurately how the school had fulfilled its educational and administrative responsibilities. This has been accepted and the original report has been withdrawn.

In both of these instances, the teachers and the school have successfully taken on the apparatus of the state. Whereas the effect of the government stance on education and its drive towards reform has 
undermined the professionalism and self-confidence of the teaching profession as a whole (and in many schools morale is very low), Te Ika Nui a Maui School has shown that if teachers are firmly grounded in their thinking and are tenacious and well-considered in standing up for what they believe, then they can be successful in defending against both direct and indirect attacks on their profession.

\section{The development of innovative learning opportunities}

Whereas the previous examples show how teachers can defend themselves against attacks on their professionalism, an important complementary side to this coin is that this same sense of commitment means that they are innovative and proactive in creating effective programmes in their professional practice. Te Ika Nui a Maui school has developed and initiated a number of projects intended to support its students in realising their potential, and has also engaged the wider community in these processes. The following are examples of this:

The Teenage Parent Unit: The school has supported the development of a centre for young (usually solo) mothers to return to school. It has also created a high quality early childcare centre so that the girls' children are looked after while they attend classes. The school has lobbied for and received government support for this initiative.

Teacher Aides: In recent years, the school has supported local adults in their re-entry into the education system through a partnership arrangement with Massey University's College of Education. Over several years, the school has sponsored the training and certification of twenty-four teacher aides on site, under the supervision of a university tutor. In return for fee sponsorship, they worked in the classrooms. Seven of the graduates are currently employed by the school, providing a well-organised and effectively developed programme of academic support. This integration of adults from the local community into the school is an important initiative. There is a body of research literature that emphasises the need for schools to support young people to construct a healthy community that does not accept extreme or outrageous behaviour. Sympathetic adults provide young people with opportunities to develop understandings of social groups and how they work. If they are well supported, they can challenge "at risk" and dangerous behaviour that in most situations goes unchallenged. The school recognises the huge importance young people place on their social context and is committed to assisting students to develop the personal skills and confidence to map out their own pathway in a safe and enabling environment.

Bullying and Leadership: For several years, the school has had a strong anti-bullying philosophy, and as an outworking of this, has developed a programme designed to develop and enhance students' leadership skills. Initially, the programme was aimed at those with pro-social behaviour, but it was decided to match each student in the programme with pro-social skills with another student with anti-social skills. Whereas students with pro-social skills are typically recognised as leaders, anti-social students are not, although they may have the same leadership abilities. Mostly they only receive negative attention because of their displays of disruptive behaviour. The positive recognition and support of leadership skills in students previously identified as anti-social has proved to be successful in turning around some of those who have been on the programme.

The Innovations Scheme for Students At Risk: The latest scheme that has been developed by the school is a Ministry of Education-sponsored scheme for students who, after identification on a series of assessment measures, can be categorised as being "at risk". The programme has been developed for students in their first year of secondary school (the third form). Although they may have already experienced failure and disaffection in large doses in their school careers, during this transition year there is often a sense of hope and openness. The purpose of the innovations programme is to provide these young people with the possibility of success. The programme is built around three complementary strategies. The first is a ten-week adventure-counselling course. Here it is intended that the students learn group skills, achieve success and develop their self-esteem, as well as meet a group of peers they may not otherwise have met. The second strategy is to identify where their weaknesses and learning gaps are in reading and writing (literacy) and mathematics (numeracy), and then to develop individualised programmes to bring them up to a skill level that is at least average for their age. The third strategy is to provide them with a mentor. This could be a slightly older peer with whom they "connect" - someone who has been through the programme before them and has achieved success, for instance - or an older person from the community who could pick them up and drive them to a sports fixture each week, and perhaps watch them play and give feedback and support. (It has 
been noted that, in this school community, many young males lack male role models and would benefit from the latter sort of mentor.)

The school has developed a philosophy for effective education,

which was articulated when it applied for funding for this initiative:

Our programme is essentially constructivist in approach. It builds upon a ten-year school wide approach adopted since our involvement in a 1991 Ministry of Education project. This professional development programme established a successful community-based programme that has been integrated into the school's curriculum and inculcated a positive, action-based, innovative methodology.

This is best demonstrated by three distinct developments:

i. The use of outdoor education both across the curriculum and as a stand-alone subject.

ii. The development of an inclusive anti-bullying school-wide approach.

iii. A willingness to challenge tradition in search of better learning outcomes.

This ethos, plus the adoption of successful "at risk" initiatives (One to One Mentoring Programme Nelson, Adventure Based Counseling and Grahame Dingle's Project K) combined with our extensive use of teacher aides and other support personnel, provides us with an excellent base from which to work. It should ensure that those students in risk of alienation remain included within the school community, while they are also given the "space" to successfully construct a realistic world view that will allow them to function appropriately within society.

\section{Discussion}

It is necessary now to consider the context-tied information in this story, in order to establish a critical dialogue with theoretical notions of school success and failure. This information includes details about the dynamic of the school and the school's interface with its community and with the education bureaucracy.

In the introduction to this article, it was demonstrated that Te Ika Nui a Maui has chosen to establish and give support to a venture that potentially offers more fundamental usefulness than would the installation of computers or widespread access to the Internet. This is not to say that the latter would not be of interest to the pupils here, just as much as it would be to those at a higher decile school. But the principal realises that there are more fundamental issues that need to be attended to first.

There is a sense of responsibility towards the children in the school's charge that is much more important than meeting the requirements of the so-called knowledge economy, or complying with a set of guidelines laid down by bureaucrats in Wellington. Fundamentally, this sense of responsibility hinges on the belief that if even a few students do not have access to school, then school is failing society. If schools provide only the trappings of success - the hardware, as it were - then the paths to those trappings will be blocked or non-existent. What Te Ika Nui a Maui has done is arguably to have opened as many pathways and methods of access to school as it can, through making it easy for solo mothers to attend, through its leadership and anti-bullying initiatives, and through its innovative programme for students at risk.

The school caters for a clientele that is generally disadvantaged, low-SES, has a large ethnic minority component, and includes large numbers who suffer from poverty and all that this entails. Staff work very hard under stress, and are always required to "go the extra mile" in dealing with the many problems that come with being a school in a disadvantaged community. It is also a situation in which there are regular ongoing crises to deal with. In the face of these difficulties, the school culture is one of problem-solving, positivity and accessibility the philosophy upon which the school is built.

In recent years, the image of teacher as folk hero (rather than the competing one of teacher as incompetent human being - "If you can't do anything else then you teach" and those who are even worse are those who teach teachers - is a compelling one. In this discussion, I examine the concept of teacher as hero. I also argue that, in providing a space not only to retain those students who are able, but also to create and support the ongoing success of more students than is normal, the school contributes to the maintenance and building of social capital in its community.

\section{Stand and deliver: The Teacher as Hero}

In Reinventing Ourselves as Teachers: Beyond Nostalgia, Mitchell and Weber (1999) devote a chapter to the possible effects of popular culture upon perceptions about teachers ("Reel to Real: Popular Culture and Teacher Identity"). They refer to several films in which the teacher is cast as hero. They mainly focus on a comparison between To Sir with 
Love and Dangerous Minds, but also mention Stand and Deliver and Dead Poet's Society. The first three films are set in low-SES communities where, despite a number of difficult challenges, a teacher is able to steer a course through a minefield of educational obstacles to give her or his students the opportunities they deserve, but have been denied. What is more, two of these films (To Sir With Love and Stand and Deliver) are based on true stories. In the first instance, Mr Tibbs chooses to stay on as a teacher in a tough London inner- city secondary school, rather than opt for a more lucrative career as an engineer, because he feels he can make a difference, and because he really cares. In the second instance, a very able Latino teacher has chosen to work with kids from his own inner-city Los Angeles ghetto, and because he is such a good teacher, is able to steer them to tremendous success in their advanced mathematics exams. When his students outperform those from affluent and privileged schools, as found in the likes of Beverly Hills 90210, it is seen as an impossibility. They are accused by the authorities of cheating. How could they possibly do so well, coming from where they do? After a series of trials and tribulations, they are cleared of this accusation. They actually did achieve this level of attainment!

These films conjure up images of individual teachers and schools taking a stance that challenges the status quo, that says they care about what happens to their students, and they are prepared to stick their necks out and to do what is right, to be in effect contemporary "Robin Hoods". When the principal of Te Ika Nui a Maui school stated that the school supported the Teenage Parent Unit because it needed doing, this was symbolic of the attitude in the school. The school had responded to the needs of its community, despite potential and real barriers from the bureaucracy that could have stopped the venture in its tracks. Now, with the Prime Minister's blessing, it is a fait accompli.

At this school there is a sense of caring, of being willing to go the extra distance. A teacher who has taught in more affluent schools and who has recently arrived there had the following to say:

If I were to compare the quality of the guidance service, the way the teachers deal with individual kids, the support they give them, the way the deans intervene, the way that I'm expected to work, the way I see the DP or AP, the way I see [the Principal] operating, ... the quality of the service given to these kids is absolutely fantastic.

I'm quite an experienced school counsellor and I've supervised counsellors in many other schools, some of which are quite high decile and are considered quite desirable. I don't believe some of their staff are as skilled as some of the ones here But it's not perceived like that because if you' re the parents of a middle-class kid you're not going to send them here, because that's not what you're looking for.

What the leadership of the school has done is to create a learning environment that is inclusive of the community and which is adapted to meet the needs of a student base, many of whom would be considered at risk or difficult to deal with. In other more affluent schools, life is much easier, the level of disruptive and anti-social behaviour is less, and there are fewer children who are not coping with the demands of school. The teachers at this school have a hard task ahead, a fact that is exacerbated by the market context in which schools with a better reputation have drained many schools like Te Ika Nui a Maui of their best academic performers (Thrupp, 1999; Lauder et al., 1999). But against these odds - and those of disadvantage and poverty - the school is having success.

\section{Social Capital}

One of the underlying themes that is emerging in the fight for success at Te Ika Nui a Maui is the idea of building and re-building communities, and the intrinsic concept of social capital. The purpose of school is to provide children with an education that prepares them to function in adult society. It provides an academic foundation and some training, and teaches people how to function within the various groups and institutions in which they will be expected to move. Fundamental to education is the provision of a value system (to complement what usually goes on at home). Schools are, in effect, microcosms of the world to come. As well as providing academic skills, they also play a very important social role in attempting to turn out grounded, confident and responsible human beings. The glue that holds communities together, and of which it can be argued the school is a fundamental component, is referred to as social capital. ${ }^{4}$ Robinson (1999) gives the following definition:

The term "social capital" refers to the social networks that help society to function effectively, the voluntary associations (including community groups, sports and cultural clubs, and residents' associations) that provide linkages between people in the community and enable them to be more effective in business, politics and a wide range of social activities. Social capital refers to the

"connectedness" between citizens. To develop social capital 
communities require high levels of trust, a range of voluntary associations, and opportunities to meet and discuss community concerns. (p. 3)

The New Zealand education reform document, Tomorrow's Schools (1988), chooses to support cultural over social capital and endorses a system where academic "smarts" seem to be all that counts. Modern psychological thought, as in Howard Gardner's (1993) concept of multiple intelligences, argues for the value of diversity, and claims that academic achievement is only one measure of educational success. It can be argued, for example, that parental commitment to local schools encourages children to form friendships that they can easily extend beyond normal school hours (which is not always easy or possible when children are driven across a city to another school). It also allows parents and their children to participate fully in the academic, social and sports activities of the school. In doing this, they can benefit from and contribute to the social capital of the school and wider community, and become generally successful, educationally. Thus, a school which places a great deal of value upon parental involvement, for example, as opposed to examination outcomes, may produce a far healthier society than one which focuses mainly on academic achievement. At the same time it can win academic achievement as a by-product. Schooling is clearly about more than academic outcomes, measurable results and competition, and the first principle of schooling must be access.

\section{Conclusion}

Many schools in lower decile areas have excellent social and academic policies and programmes, which enable students to do well and progress across a variety of fronts. Others become loser schools, and forfeit prestige, credibility, and community and financial support; they become failing institutions. Endowing them with academic trappings like computers will not do them a great deal of good if they do not have the cultural or social capital to take advantage of these trappings, and put them to good use.

Supporting such schools is important not only in the interests of social justice, but also in terms of safeguarding everyone's well-being from a large future disaffected population, that has been cast in the role of "loser". When a school like Te Ika Nui a Maui, against the odds, creates its own context and culture which are a healthy microcosm of what the larger society could be, but is not, then all is not lost.
Notes

1. For instance, from an academic outcomes point of view, for the 1999 school year, students from Te Ika Nui a Maui Secondary School did very well in Bursary and Scholarship exams. They were in the top 4 out of 21 secondary schools in their area. They were out-performed by a decile one school (with a $4.5 \%$ success rate) and were equivalent in their performance to two decile 9 schools (with a $4.0 \%$ success rate). In terms of the percentage of $A+B+C$ bursaries, $74 \%$ of students were successful with $29 \%$ receiving A Bursaries. For School Certificate for that year, their performance was good for a decile 3 school, with $49 \%$ of students receiving $A, B$ or $C$ passes.

2. Supporters of the school effectiveness movement argue that if effective management systems are in place, then schools will run well and produce better outcomes. Schools that are seen as successful in this way are often cited as examples of good practice, as the ERO does here. The theory, however, is often not matched by the practice. Things are usually more complex and nested within a mass of social and cultural issues (Thrupp \& Ball, 2001).

3. Ngati Kahungunu is one of the original Maori canoes, and its tribal area extends from Wellington up to Gisborne. A whakatauki is a Maori proverb.

4. See also O'Connell (1995)

\section{References}

Department of Education. (1988). Administering for excellence: Effective administration in education (the Picotreport). Wellington: Government Printer.

Department of Education. (1988). Tomorrow's Schools: The Reform of Educational Administration in New Zealand. Wellington: Government Printer.

Education Review Office. (1996). Improving schooling in Mangere and Otara. Wellington: ERO.

Education Review Office. (1997). Improving schooling on the East Coast. Wellington: ERO.

Education Review Office. (1998). Schooling in the Far North. Wellington: ERO.

Education Review Office. (1998). Schooling in Mangere and Otara, Progress since 1996: Follow up report. Wellington: ERO. 
Education Review Office. (1999). Good practice in Far North schools, No. 4, Winter. Wellington: ERO.

Fiske, E. B., \& Ladd, H. F. (2000). When schools compete: A cautionary tale. Washington: The Brookings Institution Press.

Gardner, H. (1993). Frames of mind: The theory of multiple intelligences. London: Fontana.

Gordon, L. (1997). Tomorrow's schools today: School choice and education quasi-market. In M. Olssen \& K. Morris-Matthews (Eds.), Education policy in New Zealand: the 1990s and beyond. Palmerston North: Dunmore Press.

Grace, G. (1990). The New Zealand Treasury and the commodification of education. In S. Middleton, J. Codd, \& A. Jones (Eds.), New Zealand Education Policy Today. Wellington: Allen \& Unwin.

Lauder, H., Hughes, D., Watson, S., Waslander, S., \& Hamlin, J. (1999). Trading in futures: Why markets in education don't work. Buckingham: Open University Press.

Mitchell, C., \& Weber, S. (1999). Reinventing ourselves as teachers: Beyond nostalgia. London and New York: Falmer Press.

O'Connell, K. (1995). Women, community and education reform: A study of the participation of women on boards of trustees. Unpublished master's thesis, Faculty of Education, Victoria University of Wellington.

Robinson, D. (Ed.). (1999). Social capital in action. Wellington: Institute of Policy Studies.

Robinson, V., Timperley, H., \& Bullard, T. (2000). Strengthening education in Mangere and Otara evaluation: Second evaluation report. Auckland UniServices Limited and Research Division, Ministry of Education, Wellington.

Sullivan, K. (1994). The impact of educational reform on teachers' professional ideologies. New Zealand Journal of Educational Studies, 29(1), 1-16.

Sullivan, K. (1997). They've opened Pandora's box: Educational reform, the New Right and teachers' ideologies. In M. Olssen \& K. MorrisMatthews (Eds.), Education policy in New Zealand: The 1990s and beyond. Palmerston North: Dunmore Press.
Sullivan, K. (1999). Teacher standards and professionalism: Contested perspectives in a decade of reform. In M. Thrupp (Ed.), New Zealand Journal of Educational Studies Special Issue: A Decade of Reform in New Zealand Education: Where to Now?, 34(1), 144-155.

Sullivan, K. (2000). A wolf in sheep's clothing: The bulk funding debate, New Zealand Annual Review of Education, 9, 79-99.

Thrupp, M. (1999). Schools making a difference: Let's be realistic! Buckingham: Open University Press.

Thrupp, M., \& Ball, S. (2001, April). Fighting for alternatives: The micropolitics of contesting British neo-liberal educational reform.. Paper presented at AERA Annual Meeting, Seattle.

Thrupp, M., \& Smith, R. (1999). A decade of ERO. In M.Thrupp (Ed.), New Zealand Journal of Educational Studies Special Issue: A Decade of Reform in New Zealand Education: Where to Now?, 34(1), 186-198.

Timperley, H., Robinson, V., \& Bullard, T. (1999). Strengthening education in Mangere and Otara evaluation: First evaluation report. University of Auckland and Research Division, Ministry of Education, Wellington.

Treasury. (1987). Government management: Brief to the incoming government 1987. Volume II Education issues. Wellington: New Zealand Government.

\section{The author}

Keith Sullivan is a Senior Lecturer in the School of Education at Victoria University of Wellington. His Email address is:

$<$ Keith.Sullivan@vuw.ac.nz $>$. 